\title{
The Effect of Social Media Culture and Knowledge Transfer on Performance
}

\author{
Dahlena Sari Marbun ${ }^{1}$, Azuar Juliandi ${ }^{2}$, Sulaiman Effendi ${ }^{3}$ \\ ${ }^{I}$ Department of Education, Universitas Islam Sumatera Utara, Indonesia \\ ${ }^{2}$ Department of Management, University of Muhammadiyah Sumatera Utara, Indonesia \\ ${ }^{3}$ Department of Education, Universitas Muhammadiyah Sumatera Utara, Indonesia \\ Dahlena@uisu.ac,id,azuajuliandi@umsu.ac.id,Sulaimanumsu@gmail.com
}

\begin{abstract}
Internet-based social media has become a part of people's lives in this era. Many people use Facebook, Whatsapp, LinkedIn, Blog and other social media to interact with each other. With social media, people exchange information and share experiences in cyberspace. Moreover, nowadays social media has become part of the organizational culture in the workplace. This study aims to analyze: (1) the influence of social media culture on knowledge transfer; (2) the influence of social media culture on work performance; and (3) the effect of knowledge transfer on work performance. The research sample consisted of 300 employees. data collection using a questionnaire. Meanwhile, the data analysis technique used partial least square. The results show that: (1) the influence of social media culture on knowledge transfer is positive and significant; (2) the influence of social media culture on work performance is positive and significant; and (3) the effect of knowledge transfer on work performance is also positive and significant.
\end{abstract}

Keywords

culture of social media; knowledge transfer; work performance

\section{Introduction}

Organizational culture is a subsystem in organizations other than subsystems such as business concepts, strategy and technology (Alvesson, 2002). In the concept of management, organizational culture means all values, attitudes, beliefs, behaviors, practices, and assumptions that are shared by members of the organization (Schein, 1985). An organization has its own unique culture. Specific characteristics of culture are developed and practiced by an organization so that it can differentiate it from other organizations (Schein, 2004).

New technology is one of the main factors affecting organizational culture changes (Kulvinskienè \& Šeimienè, 2009). In this era, many corporate organizations are using new technologies such as information technology. Companies have the potential to reach more customers or introduce new products (Shaqiri, 2015). In human resource development management, information technology has brought changes in the management and development of employees (Baloh \& Trkman, 2003).

Social media is an example of a relatively recent development of information technology. Such social media technology affects organizational performance (Anderson, 2012; Cao, Guo, Vogel, \& Zhang, 2016; Trainor, Andzulis, Rapp, \& Agnihotr, 2013). In addition, social media technology also affects knowledge transfer (Yang, Alejandro, \& Boles, 2011; Yates \& Paquette, 2011). Another study found that career success is determined by professional sites such as LinkedIn, but not on non-professional sites such as Facebook, Twitter, and MySpace (Nikitkov \& Sainty, 2014) 
Based on these important reasons, this study aims to examine how social media culture affects knowledge transfer; social media culture in influencing work performance; and knowledge transfer in influencing knowledge transfer.

\section{Review of Literature}

The main issue in this paper is social media culture. Organizational culture is the values and special characteristics in an organization (Schein E. H., 1985; Schein E. H., 2004). Currently, social media is part of organizational culture to achieve employee and company performance (Shaqiri, 2015; Baloh \& Trkman, 2003; Anderson, 2012; Cao, Guo, Vogel, \& Zhang, 2016; Trainor, Andzulis, Rapp, \& Agnihotr. , 2013).

Social media and social networking are two different terms. Social networking sites as web-based services that allow individuals to create public profiles and share connections with others in an interconnected system (Boyd \& Ellison, 2007).

Meanwhile, social media is a broader term. Social media is a web-based platform that allows workers to communicate messages to specific co-workers or broadcast messages to everyone in an organization, including sharing information files with each other with anyone and at any time within their organization (Leonardi, Huysman, \& Steinfield , 2013). Social media is quite diverse, including collaborative projects, micro blogs, blogs, content communities, social networking sites, virtual games, and virtual social worlds (Kaplan, 2012; Kietzmann, Hermkens, McCarthy, \& Silvestre, 2011). Social media like that, has been studied a lot by scientists.

In general, research shows that information technology and the internet have created a new business model (Shaqiri, 2015) and transformed staff and human resource development management (Baloh \& Trkman, 2003). In particular, many studies have examined the relationship between social media, knowledge transfer and performance. First, the study of social media relations and knowledge transfer. One of the findings of this study is that social media facilitates the transfer of knowledge and work performance (Cao, Guo, Vogel, \& Zhang, 2016). In other research, social media technology allows for tacit and explicit transfer of knowledge (Murphy, 2013). This can occur because the transfer of knowledge is made easier by social networking sites (Leonardi \& Meyer, 2015).

\section{Research Method}

This research involves qualitative research method. As explained by Creswell (1998: 15) that Qualitative research is an inquiry process of understanding based on detailed scientific traditions of inquiry that explore a social or human problem. The researcher builds a complex, holistic picture, analyzes words, reports detailed views of informants, and conducts the study in a natural setting. Whatever the approach used is a naturalistic approach because the research is done in natural conditions (natural settings) or on natural objects. Natural objects are objects that develop as they are not manipulated by researchers and the presence of researchers does not change the dynamics of these objects (Sugiyono, 2011: 14).

The data analysis technique uses interactive model analysis. Because it is considered more appropriate to meet the requirements in conducting data analysis. Interactive analysis consists of three activities that occur simultaneously, namely: data reduction, presentation 
data and drawing conclusions / verification (Miles and Huberman, 1992: 16).

Second, studies on social media relations and work performance. One study found that social media is influenced by work performance (Cao, Guo, Vogel, \& Zhang, 2016). Other research findings confirm that there is an important relationship between social media use and work performance (Leftheriotis \& Giannakos, 2014). Other studies have also proven that the interactive effects of using social media are positively related to customer relationship performance (Trainor, Andzulis, Rapp, \& Agnihotr, 2013).

Third, studies on the relationship between knowledge transfer and work performance. Knowledge has become an attractive key in the information revolution. Choosing the right information from multiple sources and turning it into useful knowledge is a major challenge (Smith, 2001). Organizations that are able to transfer knowledge effectively from one unit to another more productively are more likely to survive than those less adept at transferring knowledge (Argote, Ingram, Levine, \& Levine, 2000). One study has found that partnering knowledge and experience leads to increased performance (Makino \& Delios, 1996). Another different study shows that openness in communication is considered to have a positive influence on employee knowledge sharing, which in turn improves individual work performance (Kang, Kim, \& Chang, 2008).

The conclusions of the above studies are that there is a positive influence of social media culture on knowledge transfer; social media culture on work performance; also the transfer of knowledge on job performance. The relationships shown in Figure 1.

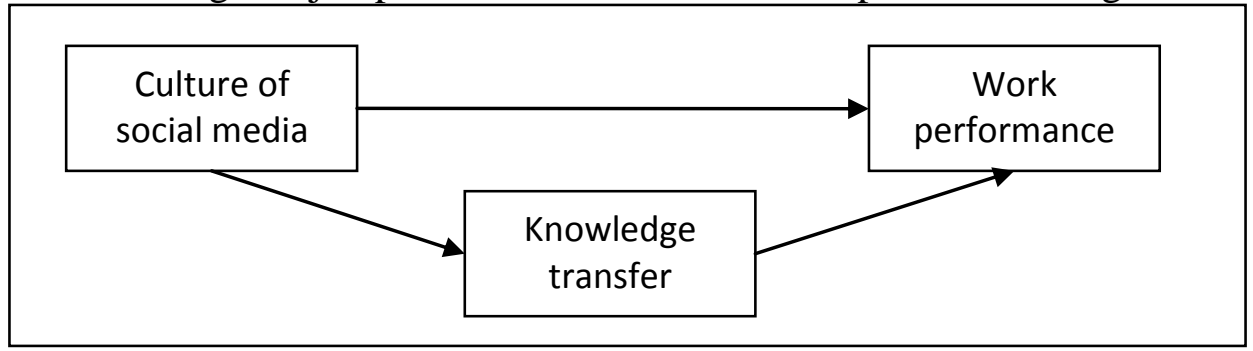

Figure 1. Conceptual framework

The approach in this study is survey research. Research respondents consisted of 100 educators (teachers) and 200 government employees (a total of 300 people) in Medan City, Indonesia. The research variables consisted of social media culture as an exogenous variable; knowledge transfer as a mediating variable, and work performance as an endogenous variable.

Measurement of these variables uses instruments adopted from various relevant studies. First, the culture of using social media uses indicators: frequency of using social media, obtaining information, building trust, sharing visions, and strengthening networks (Cao, Guo, Vogel, \& Zhang, 2016). Second, transfer of knowledge. The indicators are: Form of knowledge transferred, Mechanism of knowledge transfer, Success of knowledge transfer (Smale, 2008). Third, work performance. Indicators to measure work performance are new knowledge, increased skills / skills, changes in values, changes in behavior, improvements in conditions, and changes (Hatry, 2006).

The data analysis technique for this study uses partial least square as one of the structural equation modeling methods. Research data processing utilizes SmartPls (Ringle, Wende, \& Becker, 2015). The partial least square model used is the Reflective model. This model depicts a pattern in which arrows originate from the latent variable leading to its indicators (Figure 2). 


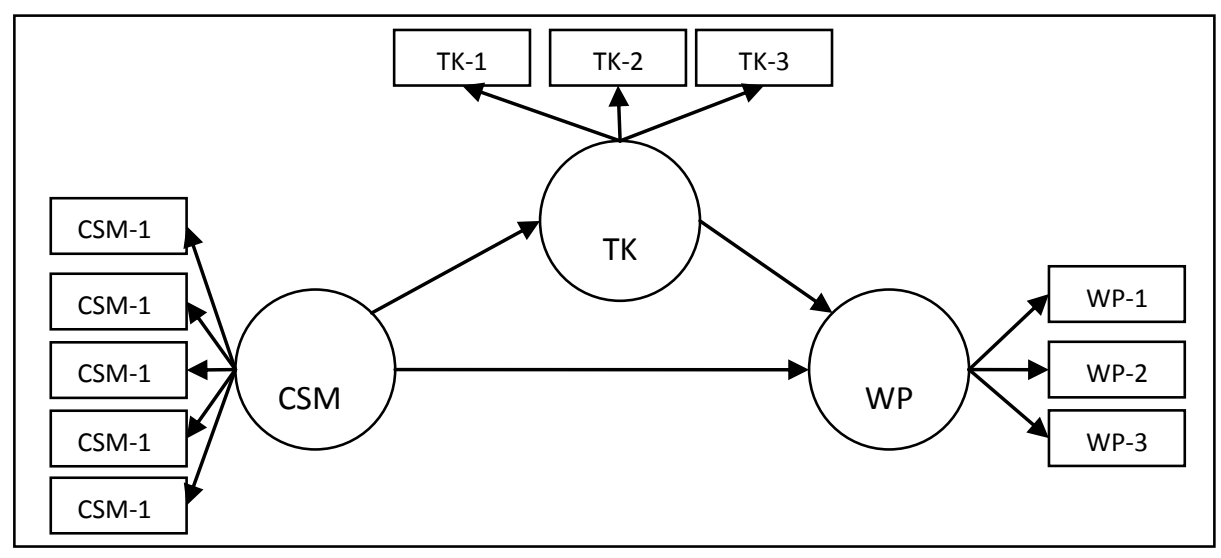

Figure 2. Reflective model dari partial least square

\section{Discussion}

This section describes four sections, including: (1) the demographics of the respondents, (2) assessing the measurement model; (3) assessing the structural model; and (4) discussion, implications and limitations.

\subsection{Respondents Demography}

Demographic characteristics of respondents are shown in Table 1. There are four characteristics that need to be known, namely gender, age, education and type of organization.

Table 1. Demographic characteristic of respondents

\begin{tabular}{|lrr|}
\hline \multicolumn{1}{|c}{ Measure } & Number & Percent \\
\hline Gender & & \\
Male & 163 & 54.33 \\
Female & 137 & 45.67 \\
\hline Age & & \\
$\quad<21$ & 2 & 0.67 \\
$21-30$ & 96 & 32.00 \\
$31-40$ & 143 & 47.67 \\
$41-50$ & 42 & 14.00 \\
$>51$ & 17 & 5.67 \\
\hline Education & & \\
High school & 51 & 17.00 \\
Diploma & 22 & 7.33 \\
Bachelor & 100 & 33.33 \\
Master & 115 & 38.33 \\
Doctorate & 12 & 4.00 \\
\hline Organizational Type & & \\
Education & 100 & 33.33 \\
Government & 200 & 66.67 \\
\hline
\end{tabular}

\subsection{Assessing the Measurement Model (Outer Model)}

Assessing the measurement model aims to evaluate the relationship between indicators and latent variables.

The first measurement model is to test the convergent validity seen from the value of outer loadings. Each indicator is expected to have an outer value greater than 0.4, especially 
for relatively new exploratory studies. However, the outer loading value is very low, which is less than 0.40, so the indicator must be removed from the variable and re-tested for convergent validity (Hair, Hult, Ringle, \& Sarstedt, 2014). All outer loading values are greater than 0.4 (Table 2). Thus, all latent variables have good convergent validity.

Table 2 Outer loadings

\begin{tabular}{lrrr}
\hline & CSM & KT & WP \\
\hline CSM-1 & .573 & & \\
CSM-2 & .703 & & \\
CSM-3 & .721 & & \\
CSM-4 & .811 & & \\
CSM-5 & .630 & & \\
KT-1 & & .713 & \\
KT-2 & & .780 & \\
KT-3 & & .811 & \\
WP-1 & & & .695 \\
WP-2 & & & .717 \\
WP-3 & & & .569 \\
WP-4 & & & .589 \\
WP-5 & & & .668 \\
WP-6 & & & .595 \\
\hline
\end{tabular}

The second measurement model is to test the construct reliability and validity. This measurement refers to the composite reliability value which must be greater than 0.6 (Bagozzi and Yi, 1988; Chin \& Dibbern, 2010). The measurement results show that all latent variables have a fairly good composite reliability value because they are greater than 0.6 (Table 3).

Table 3 Construct reliability and validity

\begin{tabular}{lc}
\hline & Composite Reliability \\
\hline CSM & .820 \\
KT & .812 \\
WP & .806 \\
\hline
\end{tabular}

The third measurement model looks at the results of discriminant validity. The reference is to look at the latest measurement criteria from discriminant validity, namely looking at the Heretroit-Monotrait Ratio (HTMT) value. If the HTMT value is less than 0.90 then a construct has good discriminant validity (Henseler, Ringle, \& Sarstedt, 2015).

Table 4 Discriminant validity

\begin{tabular}{cccc}
\multicolumn{4}{c}{ Heterotrait-Monotrait Ratio (HTMT) } \\
\hline \multicolumn{5}{c}{ CSM } & KT & WP \\
\hline CSM & & & \\
KT & .607 & & \\
WP & .358 & .413 & \\
\hline
\end{tabular}

\subsection{Assessing the Structural Model (Outer Model)}

In measuring the structural model, the first step is to test the R-Square. $\mathrm{R}^{2}$ value $=$ 0.75 (model is substantial); $\mathrm{R}^{2}=0.50$ (the model is moderate); and $\mathrm{R} 2=0.25$ (model is weak) (Hair, Hult, Ringle, \& Sarstedt, 2014; Henseler, Ringle, \& Sinkovics, 2009). The RSquare value of 0.185 shows that the ability of social media cultural variables to explain knowledge transfer is weak. Likewise, the R-Square value of 0.142 indicates that the ability 
of social media culture variables and knowledge transfer to explain work performance is also weak.

Table 5 R-Square

\begin{tabular}{lcc}
\hline & R Square & R Square Adjusted \\
\hline KT & .185 & .182 \\
WP & .142 & .137 \\
\hline
\end{tabular}

The second stage in measuring the structural model is testing the hypothesis, namely: the direct influence of social media culture on knowledge transfer; direct influence of social media culture on work performance; direct effect of knowledge transfer on job performance; and the indirect influence of social media culture on work performance that is mediated by knowledge transfer (Table 6).

Table 6 Path coefficients (direct effects)

\begin{tabular}{llcrrrr}
\hline & & $\begin{array}{c}\text { Original } \\
\text { Sample } \\
(\mathrm{O})\end{array}$ & $\begin{array}{c}\text { Sample Mean } \\
(\mathrm{M})\end{array}$ & $\begin{array}{c}\text { Standard } \\
\text { Deviation } \\
(\text { STDEV })\end{array}$ & $\begin{array}{c}\text { T Statistics } \\
(\mid \mathrm{O} / \mathrm{STDEV})\end{array}$ & $\begin{array}{c}\text { P } \\
\text { Values }\end{array}$ \\
\hline Direct Effects & CSM ->KT & .430 & .437 & .054 & 7.922 & .000 \\
& CSM -> WP & .197 & .206 & .067 & 2.965 & .003 \\
& KT -> WP & .248 & .253 & .063 & 3.944 & .000 \\
Indirect Effects & CSM -> KT -> WP & .106 & .111 & .031 & 3.449 & .001 \\
Total Effects & .304 & .316 & .063 & 3.944 & .000 \\
\hline
\end{tabular}

Figure 2. Result of partial least square analysis for R-square interpretation

The test results show that: (1) the influence of culture of social media on knowledge transfer is positive $(0.43)$ and significant $(0.000)$; (2) the influence of culture of social media on work performance is positive (0.197) and significant (0.003); and (3) the effect of knowledge transfer on work performance is positive (0.248) and significant (0.000); (4). The influence of culture of social media on work performance is not mediated by knowledge transfer (direct effects CSM $->\mathrm{WP}=0.197$ are greater than indirect effects $\mathrm{CSM} \rightarrow \mathrm{KT} \rightarrow \mathrm{WP}=$ 0.106) (Table 6).

\subsection{Discussion, Implications And Limitation}

This research has investigated the relationship between social media culture and knowledge transfer; social media culture and work performance; and transfer of knowledge and work performance.

This study found that there is a positive and significant influence between social media culture and knowledge transfer. This means that if social media is part of the organizational culture it will facilitate increased knowledge transfer. This finding is relevant to previous studies such as Shaqiri (2015); Baloh \& Trkman (2003); Cao, Guo, Vogel, \& Zhang (2016); and Leonardi \& Meyer (2015).

A positive and significant influence also occurs on the relationship between social media culture and work performance. If the social media culture in work organizations becomes a culture, it will have an impact on improving work performance. Research findings by Cao, Guo, Vogel, \& Zhang (2016); Leftheriotis \& Giannakos (2014); Trainor, Andzulis, Rapp, \& Agnihotr (2013) support the findings of this study.

Previous research from Smith (2001); Argote, Ingram, Levine, \& Levine (2000); Makino \& Delios (1996); and Kang, Kim, \& Chang (2008) are relevant to this study, because 
the relationship between knowledge transfer and job performance produces a positive and significant value.

Based on the findings of this study, the authors suggest organizational management to build a social media culture in their organization. With social media, organizational members will easily exchange information about work knowledge to achieve the goal of improving work performance.

This study has several limitations. First, the R-Square measurement shows that this research model is weak. The next research is expected to produce a more substantial (strong) model. The second limitation, the scope of this research area only analyzes workers in one city. At least the next research needs to study a wider area, namely one country.

\section{Conclusion}

In the era of information technology, organizational management must understand the culture of social media in the workplace. As the findings of this study, culture of social media is known to affect knowledge transfer and work performance, likewise knowledge transfer affects work performance.

Thus, management must rearrange its strategies for human development focusing on information technology. A culture of sharing knowledge using social media will increase the knowledge and skills of workers. The consequences of ignoring reality will hinder future organizational achievements.

\section{References}

Alvesson, M. (2002). Understanding organizational culture. London: Sage Publications.

Anderson, C. (2012). The impact of social media on lodging performance. Cornell University School of Hotel Administration, 12 (15), 6-11.

Argote, L., Ingram, P., Levine, J. M., \& Levine, J. M. (2000). Knowledge transfer in organizations: Learning from the experience of others. Organizational Behavior and Human Decision Processes, 82 (1), 1-8.

Bagozzi, R. P., \& Yi, Y. (1988). On the evaluation of structural equation models. Journal of the academy of marketing science, 16(1), 74-94.

Baloh, P., \& Trkman, P. (2003). Influence of internet and information technology on work and human resource management. Informing Science \& IT Education Conference (pp. 498-505). California: Informing Science Institute.

Boyd, D. M., \& Ellison, N. B. (2007). Social network sites: Definition, history, and scholarship. Journal of Cimputer-Mediated Communication , 13(1), 210-230.

Cao, X., Guo, X., Vogel, D., \& Zhang, X. (2016). Exploring the influence of social media on employee work performance. Internet Research , 26(2), 529-545.

Chin, W. W., \& Dibbern, J. (2010). An introduction to a permutation based procedure for multi-group PLS analysis: Results of tests of differences on simulated data and a cross cultural analysis of the sourcing of information system services between Germany and the USA. In V. E. Vinzi, W. W. Chin, J. Henseler, \& H. Wang (Eds.), Handbook of partial least squares: Concepts, methods and applications. Verlag Berlin Heidelberg: Springer.

Hair, J. E., Hult, G. M., Ringle, C. M., \& Sarstedt, M. (2014). A primer on partial least squares structural equation modeling ( PLS-SEM). Los Angels: SAGE Publications. 
Henseler, J., Ringle, C. M., \& Sinkovics, R. R. (2009). The use of partial least squares path modeling in international marketing. Advances in International Marketing, 20. 277320.

Henseler, J., Ringle, C. M., \& Sarstedt, M. (2015). A new criterion for assessing discriminant validity in variance-based structural equation modeling. Journal of the academy of marketing science, 43(1), 115-135.

Kang, Y.-J., Kim, S.-E., \& Chang, G.-W. (2008). The impact of knowledge sharing on work performance: An empirical analysis of the public employees' perceptions in South Korea. International Journal of Public Administration, 31 (14), 1548-1568.

Kaplan, A. M. (2012). If you love something, let it go mobile: mobile marketing and mobile social. Business Horizons , 53 (1), 129-139.

Kietzmann, J. H., Hermkens, K., McCarthy, I. P., \& Silvestre, B. S. (2011). Social media? Get serious! Understanding the functional building blocks of social media. Business Horizons , 54 (3), 241-251.

Kulvinskienè, V. R., \& Šeimienè, E. S. (2009). Factors of organizational culture change. Ekonomika, 87 (1), 27-43.

Leftheriotis, I., \& Giannakos, M. N. (2014). Using social media for work: Losing your time or improving your work? Computers in Human Behavior , 31 (1), 134-142.

Leonardi, P. M., \& Meyer, S. R. (2015). Social Media as Social Lubricant: How Ambient Awareness Eases Knowledge Transfer. American Behavioural Scientist , 59 (1), 10-34.

Leonardi, P. M., Huysman, M., \& Steinfield, C. (2013). Enterprise social media: Definition, history, and prospects for the study of social technologies in organizations. Journal of Computer-Mediated Communication, 19 (1), 1-19.

Makino, S., \& Delios, A. (1996). Local Knowledge Transfer and Performance: Implications for Alliance Formation in Asia. Journal of International Business Studies , 27 (5), 905927.

Murphy, G. (2013). Using social media to facilitate knowledge transfer in complex engineering environments: A primer for educators. European Journal of Engineering Education , 38 (1), 70-84.

Nikitkov, A., \& Sainty, B. (2014). How significant are users' opinions in social media? International Journal of Accounting \& Information Management, 22 (4), 273-294.

Ringle, C.,Wende, W. S., \& Becker, J. M. (2015). SmartPLS 3. Boenningstedt: SmartPLS $\mathrm{GmbH}$.

Schein, E. H. (1985). Organizational culture and leadership. Sanfransisco CA: Jossey Bass.

Schein, E. H. (2004). Organizational culture and leadership. San Francisco: Jossey-Bass, John Wiley \& Sons.

Shaqiri, A. B. (2015). Impact of information technology and internet in businesses. Academic Journal of Business, Administration, Law and Social Sciences , 1 (1), 73-79.

Smith, E. A. (2001). The role of tacit and explicit knowledge in the workplace. Journal of Knowledge Management , 5 (4), 311 - 321.

Trainor, K. J., Andzulis, J. M., Rapp, A., \& Agnihotr, R. (2013). Social media technology usage and customer relationship performance: A capabilities-based examination of social CRM. Journal of Business Research, 67 (6), 1201-1208.

Yang, J., Alejandro, T. G., \& Boles, J. S. (2011). The role of social capital and knowledge transfer in selling center performance. Journal of Business \& Industrial Marketing , 26 (3), $152-161$.

Yates, D., \& Paquette, S. (2011). Emergency knowledge management and social media technologies: A case study of the 2010 Haitian earthquake. International Journal of Information Management , 31 (1), 6-11. 